\title{
IMPLEMENTASI KEBIJAKAN GERBANG EMAS BERSINAR DALAM MENGUKUR IPM DI KABUPATEN TABALONG
}

\author{
Anang Syakhfiani ${ }^{1}$, Sampara Lukman ${ }^{2}$, Khasan Effendy ${ }^{3}$, Marja Sinurat ${ }^{4}$ \\ ${ }^{1,2,3,4}$ Instititut Pemerintahan Dalam Negeri (IPDN) \\ Email: anang.syakhfiani@gmail.com
}

\begin{abstract}
Abstrak
Dalam sepuluh tahun terakhir Indeks Pembangunan Manusia (IPM) di Kabupaten Tabalong Provinsi Kalimantan Selatan selalu bearada di urutan bawah dari seluruh kabupaten/Kota yang ada yaitu antara urutan 9 dan 10, hal ini sangat miris karena bertolak belakang dengan kondisi Kabupaten Tabalong yang kaya akan sumber daya alam. Sehubungan dengan hal tersebut pemerintah daerah berupaya untuk mencari cara untuk dapat meningkatkan IPM agar dapat menyusul ketertinggalan dari daerah lain. Program Gerbang Emas Bersinar yang dimulai sejak tahun 2015 oleh pemerintah daerah yang menyasar terutama pada bidang ekonomi, kesehatan pendidikan dan kesejahteraan rakyat ternyata mampu meningkatkan IPM Kabupaten Tabalong yang sebelumnya selalu berada di peringkat bawah dalam beberapa tahun terakhir selalu berada di dalam 5 besar. Penelitian ini akan menjelaskan bagaimana Kebijakan Gerbang Emas Bersinar dapat berkontribusi dalam peningkatan IPM di Kabupaten Tabalong.
\end{abstract}

Kata Kunci: Kebijakan, Indeks Pembangunan Manusia, Pemerintah

\begin{abstract}
In the last ten years the Human Development Index (HDI) in Tabalong Regency, South Kalimantan Province has always been at the bottom of all regencies/cities, namely between 9th and 10th, this is very sad because it is contrary to the condition of Tabalong District which is rich in Natural Resource. In connection with this the local government is trying to find ways to improve HDI so that it can catch up with other regions. Gerbang Emas Bersinar Program, which began in 2015 by local governments targeting mainly in the fields of economy, health education and people's welfare, was able to improve the HDI of Tabalong Regency, which had always been ranked lower in the last few years, always in the top 5. This research will explain how tGerbang Emas Bersinar Policy can contribute to the improvement of HDI in Tabalong Regency.
\end{abstract}

Keywords: Policy, Human Development Index, Government.

\section{A. PENDAHULUAN}

Otonomi daerah secara langsung memberikan dampak terhadap kemandirian daerah pada setiap aspek khususnya kebijakan serta aktivitas Pemerintahan, termasuk dalam konteks perencanaan daerah. Sejalan dengan pandangan Rencana Pembangunan Jangka Panjang (RPJP) nasional, Pemerintah harus menghantarkan masyarakat Indonesia kepada kemakmuran, kesejahteraan lahir dan batin, serta harus mengatasi masalah jangka panjang seperti masalah pertumbuhan ekonomi (Arsyad,.dkk., 2011). Sedangkan di dalam jangka 
pendek Pemerintah dituntut untuk selalu dapat membantu menciptakan iklim usaha yang kondusif atau mendukung semua pihak, seiring dengan pengentasan masalah-masalah ekonomi jangka pendek. Keberhasilan program jangka pendek dirasa penting, mengingat keberhasilan pemerintah tidak terlepas dari kemampuanya menangani masalah-masalah ekonomi jangka pendek.

Kondisi tersebut memberikan keleluasaan bagi Pemerintah Daerah dalam membentuk berbagai kebijakan yang memberikan benefit terhadap kesejahteraan masyarakatnya. Setiap daerah memiliki metode masing-masing dalam membentuk kebijakan yang sesuai dengan karakteristik daerahnya. Tercapainya kondisi suitable antara kebijakan dari Pemerintah dan masyarakat sebagai penerima dampak, yang diharapkan dapat menjadikan kebijakan tersebut berhasil. Hal tersebut sejalan dengan juga terjadi di Kabupaten Tabalong dalam membentuk gerakan dan kebijakan dalam percepatan peningkatan Indeks Pembangunan Manusia (IPM). Salah satunya melalui gerakan Gerbang Emas Bersinar yang menjadi Gerakan dan kebijakan percepatan peningkatan IPM.

Gerbang Emas Bersinar tersebut muncul karena adanya political will dari Kepala Daerah Kabupaten Tabalong dalam meningkatkan Indeks Pembangunan Manusia (IPM) yang dibentuk melalui regulasi kebijakan antara lain:

1. Peraturan Bupati Tabalong Nomor 18 Tahun 2015 tentang Pedoman Gerakan Pembangunan Menuju Masyarakat Sejahtera Bersinar di Kabupaten Tabalong.

2. Peraturan Bupati Tabalong tentang Pelaksanaan Kredit Gerbang Emas

3. Peraturan Daerah Kabupaten Tabalong Nomor 07 Tahun 2015 tentang Pengelolaan Tanggung jawab Sosial dan Lingkungan Perusahaan.

Secara filosofis, gerakan tersebut didasari pada buruknya nilai IPM Kabupaten Tabalong yang tidak sejalan dengan sumber daya alam yang dimilikinya. Sebuah fenomena ironis yang dikenal dengan teori "kutukan sumber daya alam" (the resource curse/the paradox of plenty) yang menyatakan bahwa negara yang kaya akan sumber daya alam, terutama yang tak terbarukan seperti minyak dan hasil tambang, cenderung lebih lambat pertumbuhan ekonominya jika dibandingkan dengan negara yang terbatas sumber daya alamnya menjadi salah satu landasan mengapa Gerakan tersebut lahir.

Kondisi demikian dirasa oleh Pemerintah Kabupaten Tabalong SDA yang melimpah tidak memberikan pengaruh terhadap kondisi pada kualitas IPM yang baik. Tinjauan tersebut, Melalui sebuah tabel sebagai berikut: 
ARTIKEL

Tabel 1 Peringkat Indeks Pembangunan Manusia (IPM) Kalimantan Selatan

Data Kabupaten/ Kota Tahun 2004-2013

\begin{tabular}{|c|c|c|}
\hline Tahun & IPM & $\begin{array}{c}\text { Peringkat IPM Kabupaten/Kota } \\
\text { Kalimantan Selatan }\end{array}$ \\
\hline 2004 & 67.2 & Peringkat 10 \\
\hline 2005 & 67.6 & \\
\hline 2006 & 68.27 & Peringkat 9 \\
\hline 2007 & 68.51 & \\
\hline 2008 & 68.95 & Peringkat 7 \\
\hline 2009 & 69.45 & Peringkat 9 \\
\hline 2010 & 70 & Peringkat 8 \\
\hline 2011 & 70.45 & Peringkat 10 \\
\hline 2012 & 71.05 & Tah 2004 \\
\hline 2013 & 71.56 & \\
\hline
\end{tabular}

Sumber: BPS Kalimantan Selatan Tahun 2004-2013

Berdasarkan tabel di atas menunjukkan bahwa Kabupaten Tabalong dalam peringkat IPM di antara Kabupaten/Kota Kalimantan pada tahun 2004 menempati posisi peringkat ke10. Posisi IPM tersebut dirasa belum memuaskan oleh Pemerintah Kabupaten Tabalong, kondisi ini juga dilihat dari tabel tersebut IPM menunjukkan 9 tahun kembali pada peringkat ke-10 walaupun terjadi. Kondisi tersebut diamati dan menjadi dasar dorongan untuk membentuk suatu strategi dalam peningkatan IPM dalam rangka memajukan kawasan dan peningkatan kesejahteraan masyarakat. Maka Pemerintah Kabupaten Tabalong untuk dapat mensinergiskan antara keinginan dan Program Pemerintah Pusat melalui Gerbang Emas Bersinar. Program tersebut menjadi diimplementasikan secara komprehensif dan terpadu untuk melaksanakan pembangunan desa secara sinergis dengan memberdayakan semua stakeholder dan seluruh sumber daya yang tersedia guna meningkatkan kesejahteraan masyarakat dan mewujudkan kemandirian pedesaan.

\section{B. TINJAUAN PUSTAKA}

\section{Kebijakan}

Kebijakan menurut Thomas R. Dye, (1978, 3) seperti yang diungkapkan ialah, “policy is whatever goverments chose to do or not to do". Artinya, kebijakan adalah apa yang pemerintah pilih untuk melakukan atau tidak melakukan. Pengertian tersebut dipahami bahwa kebijakan merupakan sebuah pilihan dan terdapat unsur dalam menetapkan suatu prioritas. Merujuk pada pandangan tersebut, sebenarnya menunjukkan bahwa kebijakan memiliki sifat temporer. Sifat tersebut mengacu terhadap bagaimana kita merancang dan mengkonstruksi sebuah kejadian atau pengalaman yang dapat dimengerti atau jelas dalam term waktu. Waktu tidak dapat dipisahkan dari hal-hal, kejadian, proses dan merupakan bagian atau melekat dari 
seluruh entitas empiris. Pertama, pada tiap pilihan kebijakan atau keputusan bergantung pada opsi pengetahuan dan di mana sebuah konsep peluang merupakan sebuah hal yang fundamental. Kedua, peluang tidak bisa dialienasikan terkait dengan temporalitas: tanpa menyadari sebuah masa lalu, sekarang atau masa depan, gagasan kemungkinan dan pilihanpilihan tersebut menjadi tidak masuk akal (Adrian, 2006:3-4).

Model implementasi kebijakan menurut Grindle (1980) dalam Wibawa (1994:22-25) bahwa implementasi kebijakan ditentukan oleh isi kebijakan dan kontek implementasinya, ide dasarnya adalah bahwa setelah kebijakan di transformasi barulah kebijakan dilakukan, keberhasilannya ditentukan oleh derajad implementabilitynya dari program itu, isi kebijakan tersebut mencakup hal-hal sebagai berikut: Pertama, kepentingan yang dipengaruhi oleh kebijakan, kedua, tipe atau jenis manfaat yang akan dihasilkan, ketiga, derajat perubahan yang diinginkan, keempat, kedudukan pembuat kebijakan, kelima, siapa pelaksana program dan keenam, sumberdaya yang dilibatkan.

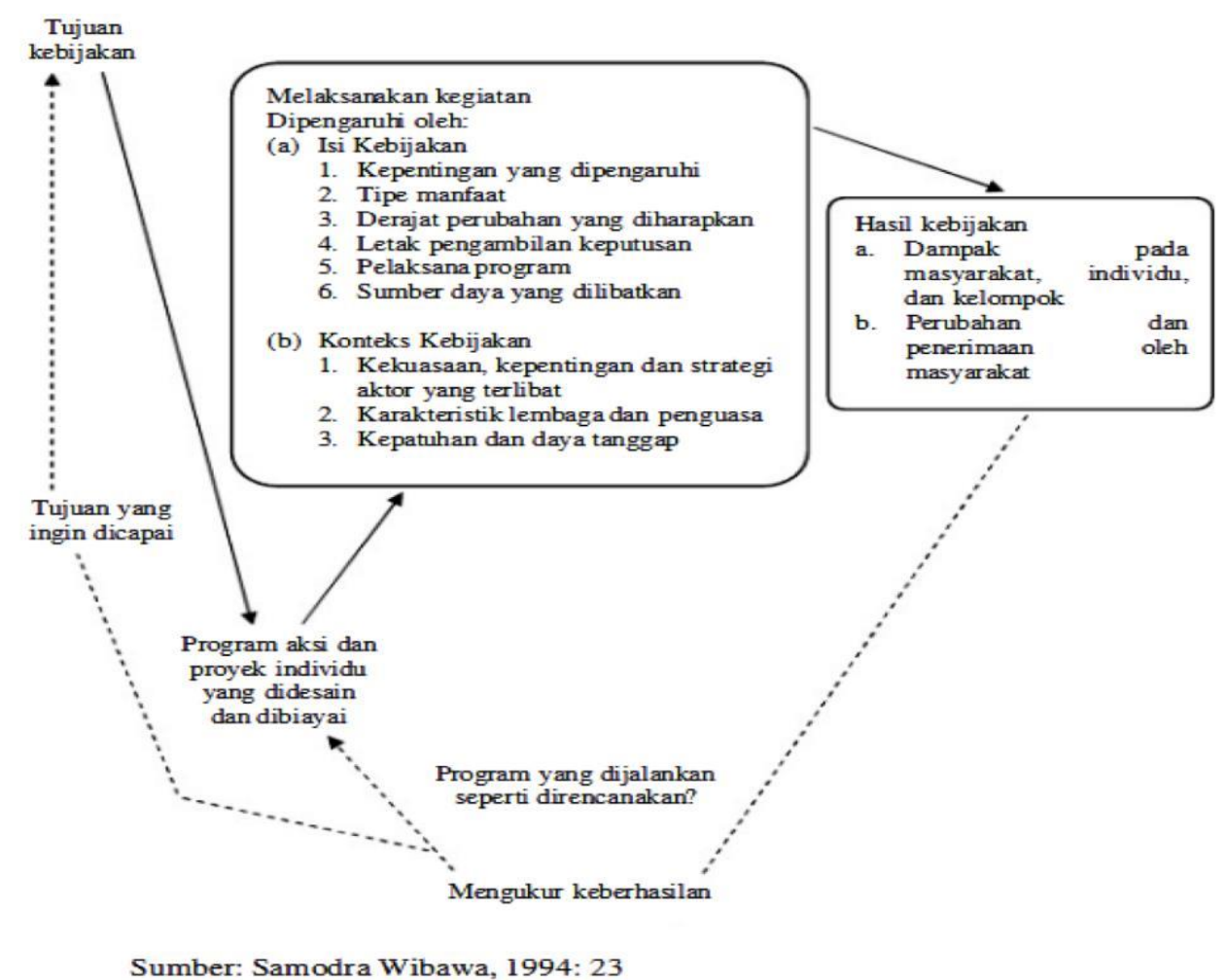

\section{Gambar 1 Model Implementasi Kebijakan Merilee S Grindel (1980)}

Dalam bukunya Merilee S Grindel yang berjudul Politics and Policy Implementation in the Third Word menyatakan bahwa tugas dan fungsi implemtasi menciptakan relasi dan koneksi yang mengijinkan tujuan kebijakan public untuk direaslisasikan menjadi sebuah hasil dan aktifitas pemerintah, sementara aktifitas pemerintah akan diwujudkan melalui program 
dan proyek individu, dimana dapat dianggap sebagai hasil program yang sudah dijakankan. Keberhasilan dan kegagalan suatu implementasi kebijakan dijadikan sebagai pedoman untuk perumusah kebijakan selanjutnya.

Pendekatan Grindel dikenal dengan Implementation as a Political and Administrative Procces, dimana terdapat dua variabel yang mempengaruhi implementasi kebijakan publik, yaitu sebagai berikut:

a. Keberhasilan implementasi suatu kebijakan public dapat diukur dari proses pencapaian hasil akhir (outcome), yaitu tercapai atau tidaknya tujuan yang ingin diraih, dimana pengukuran keberhasilan dapat dilihat dari 2 hal, yaitu:

1). Dilihat dari prsesnya dengan mempertanyakan apakah pelaksanaan kebijakan sesuai dengan yang ditentukan (design) dengan merujuk pada aksi kebijakannya.

2). Apakah tujuan kebijakan tercapai, dimensi ini diukur dengan melihat dua factor yaitu, dampak atau efeknya kepada masyarakat secara individua tau kelompokdan tingkat perubahan yang terjadi serta penerimaan kelompok sasaran dan perubahan yang terjadi.

b. Keberhasilan suatu implementasi kebijakan public, ditentukan oleh tingkat implementasi kebijakan itu sendiri, yang terdiri atas isi kebijakan atau content of policy yang mencakup:

1). Interest Affected (kepentingan-kepentingan yang mem pengaruhi)

Interest affected berkaitan dengan berbagai kepentingan yang mempengaruhi suatu implementasi kebijakan. Indicator ini berargumen bahwa suatu kebijakan dalam pelaksanaanya pasti melibatkan banyak kepentingan, dan sejauh mana kepentingan-kepentingan tersebut membawa pengaruh terhadap implementasinya.

2). Type of Benefits (tipe manfaat)

Tipe manfaat berupaya untuk menunjukan atau menjelaskan bahwa dalam suatu kebijakan harus terdapat beberapa jenis manfaat yang menunjukan dampak positif yang dihasilkan oleh pengimplemntasikan kebijakan yang hendak dilaksanakan.

3). Extent of Change Envision (derajat perubahan yang ingin dicapai)

Setiap kebijakan memiliki target yang hendak dan ingin dicapai isi dari kebijakan yang ingin dijelasksan pada poin ini adalah sejauhmana perubahan yang diinginkan dari sebuah kebijakan haruslah memiliki skala yang jelas. Suatu program ytang bertujuan mengubah sikap dan perilaku kelompok sasaran relative lebih sulit di implemntasikan daripada program yang sekedar memberikan bantuan kepada masyarakat miskin. 
4). Site of decision making (letak pengambilan keputusan)

Pengambilan keputusan dalam suatu kebijakan memegang peranan penting dalam pelaksanaan suatu kebijakan, maka pada bagian ini harus dijelaskan dimana letak pengambilan keputusan dari suatu kebijakan yang akan di implemtasikan, apakah letak sebuah program sudah tepat.

5). Program Implementer (pelaksana program)

Dalam menjalankan suatu kebijakan atau program harus didukung dengan adanya pelaksanaan kebijakan yang kompeten dan kapabel demi keberhasilan suatu kebijakan dan ini haru sudah terdata dengan baik, apakah sebuah kebijakan telah menyediakan implementator dengan rinci.

6). Resource Committed (sumber-sumber daya yang digunakan)

Apakah sebuah program didukung oleh sumber daya yang memadai, pelaksana kebijakan harus didukung oleh sumberdaya -sumberdaya yang mendukung agar pelaksanaan berjalan dengan baik.

Untuk lingkungan implementasi (context of implementation) terdiri dari beberapa variable yaitu:

a. Power, Interest, and Strategy of Actor Involved (Kekuasaan, KepentinganKepentingan, dan Strategi dari Aktor yang Terlibat)

Dalam suatu kebijakan perlu dipertimbangkan pula kekuatan atau kekuasaan, kepentingan serta strategi yang digunakan oleh para actor yang terlibat guna memperlancar jalannya pelaksanaan suatu implementasi kebijakan. Bila hal ini tidak diperhitungkan dengan matang, sangat besar kemungkinan program yang hendak diimplementasikan akan jauh hasilnya dari yang diharapkan.

b. Institution and Regime Characteristic (Karakteristik lembaga dan penguasa)

Lingkungan dimana suatu kebijakan tersebut dilaksanakanjuga berpengaruh terhadap keberhasilannya, maka pada bagian ini ingin dijelaskan karakteristik dari suatu lembaga yang akan turut mempengaruhi suatu kebijakan.

c. Compliance and Responsiveness (Tingkat Kepatuhan dan Adanya Respon dari Pelaksana)

Hal lain yang dirasa penting dalam proses pelaksanaan suatu kebijakan adalah kepatuhan dan respon dari para pelaksana, maka yang hendak dijelaskan pada poin ini adalah sejauhmana kepatuhan dan respon dari pelaksana dalam menanggapi suatu kebijakan. 
Setelah kegiatan pelaksanaan kebijakan yang dipengaruhi oleh isi atau konten dan lingkungan atau konteks diterapkan, maka akan dapat diketahui apakah para pelaksana kebijakan dalam membuat sebuah kebijakan sesuai dengan apa yang diharapkan, juga dapat diketahui pada apakah suatu kebijakan dipengaruhi oleh suatu lngkungan, sehingga terjadinya tingkat perubahan yang terjadi.

Menurut Grindle (1980), keberhasilan implementasi kebijakan publik dipengaruhi oleh dua variabel yang fundamental, yakni isi kebijakan (content of policy) dan lingkungan implementasi (context of implementation) seperti terlihat pada gambar di atas. Variabel isi kebijakan ini mencakup: (1) sejauh mana kepentingan kelompok sasaran atau target groups termuat dalam isi kebijakan; (2) jenis manfaat yang diterima oleh target groups, (3) sejauhmana perubahan yang diinginkan dari sebuah kebijakan. Suatu program yang bertujuan mengubah sikap dan perilaku kelompok sasaran relative lebih sulit diimplementasikan dari pada program yang sekedar memberikan bantuan atau kredit kepada masyarakat miskin; (4) apakah letak sebuah program sudah tepat. (5) apakah sebuah kebijakan telah menyebutkan implementornya dengan rinci; dan (6) apakah sebuah program didukung oleh sumber daya yang memadai. Sedangkan variabel lingkungan kebijakan mencakup: (1) Seberapa besar kekuasaan, kepentingan, dan strategi yang dimiliki oleh para actor yang terlibat dalam implementasi kebijakan, (2) Karakteristik Lembaga dan penguasa yang sedang berkuasa, (3) Tingkat kepatuhan dan responsivitas kelompok sasaran.

\section{Pemerintah}

Menurut Ndraha (2011:7), Pemerintahan didefinisikan sebagai proses pemenuhan kebutuhan manusia sebagai konsumer (produk-produk pemerintahan), akan pelayanan publik dan pelayanan civil, badan yang berfungsi sebagai prosesor (pengelola, provider)-nya disebut pemerintah; konsumer produk-produk pemerintahan disebut yang diperintah; hubungan personil pemerintah disebut aktor pemerintah; dan aktor yang melkukan tugas tertentu disebut artis pemerintah.

Pengertian pemerintahan menurut Syafiie (2019:19), dapat diartikan: 1) Pemerintah berarti melakukan pekerjaan menyuruh, yang berarti memiliki empat unsur yaitu, terdiri dari dua pihak, unsur yang diperintah yaitu rakyat, unsur yang memerintah yaitu pemerintah itu sendiri dan antar keduanya ada hubungan, 2) setelah ditambah awalan "pe" menjadi pemerintah yang berarti badan atau organisasi yang mengurus, 3) setelah ditambah akhiran "an" menjadi pemerintahan, yang berarti perbuatan, cara atau perihal. 
Selanjutnya (Suradinata, 2004) pengertian pemerintahan adalah lembaga atau badanbadan politik yang mempunyai fungsi melakukan upaya untuk mencapai tujuan negara, sedangkan pemerintahan adalah semua kegiatan lembaga atau badan-badan publik tersebut dalam menjalankan fungsinya untuk mencapai tujuan negara. Berdasarkan pengertian tersebut, dapat disimpulkan bahwa pemerintahan pada hakikatnya adalah aspek statis sedangkan pemerintahan adalah aspek dinamikanya.

Menurut Effendy (2010, 61), dalam konteks sosiologi pemerintahan secara esensial merupakan suatu proses pengambil keputusan dan proses bagaimana keputusan dilaksanakan atau tidak diimplementasikan secara konseptual pemahaman tersebut dimaksudkan untuk menjamin keberlanjutan kekuasaan dan pemeriksaan kinerja pelaku pemerintahan diperlukan interaksi antara pemerintah yang diperintah melalui koridor sistem konstruktif dan dinamis dalam membangun kinerja siapa, mengerjakan apa dan bertanggungjawab pada siapa dengan hasil apa dan memuaskan siapa.

Pemerintahan dibentuk dengan maksud untuk membangun peradaban dan menjaga sistem ketertiban sosial sehingga masyarakat bisa menjalani kehidupan secara wajar dalam konteks kehidupan bernegara. Dalam perkembangannya, konsep pemerintahan mengalami transformasi paradigma dari yang serba negara ke orientasi pasar (market or public interest), dari pemerintahan yang kuat, besar dan otoritarian ke orientasi small and less government, egalitarian dan demokratis, serta transformasi sistem pemerintahan dari yang sentralistik ke desentralistik (Bappenas, 2004).

\section{METODE}

Pendekatan yang digunakan dalam penelitian ini adalah pendekatan kualitatif, dengan metode eksploratoris. Metode penelitian kualitatif sebagai prosedur penelitian yang menghasilkan data deskriptif berupa kata tertulis atau lisan dari orang-orang dan perilaku yang dapat diamati. Penelitian kualitatif lebih menghendaki arah bimbingan penyusunan teori substantif yang berdasarkan data. Penggunaan pendekatan kualitatif juga disesuaikan dengan karakteristik yang ada bahwa peneliti secara langsung terlibat di lokasi penelitian melalui pengamatan peran serta (participant observation).

Desain penelitian bersifat ekploratoratif, dimana menemukan fakta dengan interprestasi dalam melukiskan secara akurat sifat dari beberapa fenomena kelompok atau individu yang berasal dari hasil temuan penelitian. Irawan (2000:59), juga menyatakan bahwa metode yang bersifat eksploratoris merupakan pemahaman paling dangkal terhadap sesuatu melalui penelitian survey dengan mengandalkan kuesioner atau observasi sekilas sebagai 
instrumen pengumpulan data. Jadi, dengan metode eksploratif maka pendekatan yang digunakan juga merupakan pendekatan kualitatif. Pendekatan kualitatif tersebut digunakan dalam penelitian ini untuk mengungkapkan secara komprehensif dan alami bagaimana proses perencanaan pembangunan daerah Gerbang Emas "Bersinar" dalam mewujudkan masyarakat desa sejahtera di Kabupaten Tabalong Provinsi Kalimantan Selatan.

Penggunaan pendekatan metode kualitatif menekankan kepada permasalahan mengenai apa adanya (das sein) dengan kenyataan yang ada di lapangan melalui kata-kata lisan atau tertulis dari orang dan perilaku yang diamati. Metode Implementasi Kebijakan Gerbang Emas bersinar ini Mengambil model Implementasi kebijakan yang dikemukakan oleh Merilee S. Grindle (1980) yang dipengaruhi oleh dua variabel yang fundamental, yakni isi kebijakan (content of policy) dan lingkungan implementasi (context of implementation).

\section{HASIL DAN PEMBAHASAN}

\section{Konten Kebijakan}

a. Kepentingan Kebijakan yang Terpengaruh oleh Kebijakan Gerbang Emas Bersinar Kebijakan program Gerbang Emas Bersinar yang dilakukan Pemerintah Kabupaten Tabalong menyentuh pada kepentingan kesejahteraan masyarakat. Secara objektif Gerbang Emas Bersinar untuk memajukan IPM masyarakat yang cenderung dirasa perlu dari pihak Pemerintah Kabupaten mengupayakan peningkatan kesejahteraan melaluo peningkatan IPM. IPM Kalimantan Selatan dan kondisi empirik di mana potensi SDA yang melimpah tidak diiringi dengan kondisi SDM Kabupaten Tabalong. Fenomena tersebut direfleksikan Pemerintah Kabupaten Tabalong, di mana beberapa tahun peringkat IPM tidak mencapai angka ke urutan 5 besar hingga sebelum dilaksanakan Gerbang Emas Bersinar, di tahun 2013 Kabupaten Tabalong hanya menempati posisi ke-10 di Kalimantan Selatan.

Kepentingan yang dominan terlihat bahwa Pemerintah Kabupaten menginginkan adanya perubahan dalam peningkatan IPM yang sekaligus menggerakan pemerintah untuk melibatkan berbagai kepentingan untuk mensukseskan program Gerbang Emas Bersinar. Demikian mendorong pemerintah untuk melakukan berbagai kebijakan seperti; Kredit UMKM 0\%, Gemas Mekar untuk peningkatan kualitas dan harga komoditas karet, penyediaan pasar komoditas, serta pemanfaatan dana CSR untuk sarana fasilitas transportasi pendidikan.

b. Tipe Manfaat

Manfaat Gerbang Emas Bersinar diupayakan memberikan dampak peningkatan IPM yang menyentuh berbagai aspek utama ekonomi, pendidikan, dan kesehatan. Program JURNAL PAPATUNG: Vol. 3 No. 1 Tahun 2020 
Gerbang Emas yang sudah dilaksanakan memberikan manfaat terhadap masyarakat diantaranya memberikan kemudahan dalam permodalan usaha dengan Kredit $0 \%$ sekaligus pengentasan permasalahan sosial tindak praktik rentenir berkedok koperasi di tengah-tengah masyarakat. Pemberian Kredit juga diiringi dengan pembekalan dalam bentuk pelatihan dan pengembangan yang disokong oleh dinas teknis dalam mengelola usaha contohnya pembelian bibit yang tidak merusak ekosistem.

Manfaat program juga mendorong terjadinya intensifikasi atau nilai tambah terhadap produk komoditas masyarakat seperti Gemas Mekar hingga menciptakan keberlanjutan dalam menyediakan pasar untuk hasil komoditi melalui Perumda Karet Kabupaten Tabalong yang disokong dengan perbankan dan koperasi daerah, sehingga harga dari petani karet terhadap karetnya dapat dikontrol dan cenderung lebih stabil.

c. Derajat Perubahan yang ingin dicapai

Pemerintah Kabupaten Tabalong menanggapi adanya permasalahan yang diindikasikan tidak seimbangnya antara sumber daya yang berlimpah dengan pembangunan masyarakat. Fenomena ini ditinjau dengan merujuk pada angka IPM Kabupaten Tabalong pada tahun 2004-2013 peningkatan menempati posisi ke-10 dari 13 Kabupaten di Kalimantan Selatan. Pemerintah Kabupaten Tabalong menginisiasikan Program Gerbang Emas Bersinar untuk meningkatkan IPM pada tahun 2014. Inisiasipun menghasilkan pencapaian yang baik, di mana berdasarkan Badan Pusat Statistik pada tahun 2014 IPM Kabupaten Tabalong mencapai pada posisi ke-3 Kalsel yang bertahan sampai saat ini.

\section{d. Letak Pengambilan Keputusan}

Program Gerbang Emas Bersinar Kabupaten Tabalong cenderung memiliki karakteristik kebijakan top-down yang sekaligus menempatkan bahwa letak pengambilan keputusan berada di Kepala Daerah dan DPRD. Posisi pengambilan kebijakan dilihat dari political will atau inisiatif program berasal dari Pemerintah Kabupaten Tabalong untuk kesejahteraan masyarakat bukan berasal dari tuntutan masyarakat untuk mendorong kebijakan. Kemudian dalam konten implementasi kebijakan DPRD juga turut andil dalam mendukung terbitnya Peraturan Daerah No. 31 Tahun 2017 tentang Pedoman Pelaksanaan Kredit Gerbang Emas. Artinya Kepala Daerah Kabupaten Tabalong dan DPRD terhadap program Gerbang Emas Bersinar yang terdapat kesamaan visi dan misi yang sekaligus memberikan kekuatan kebijakan dalam implementasi pengembangan dan perencanaan kebijakan Gerbang Emas Bersinar secara bersama-sama. Akan tetapi kecenderungan tersebut harus disadari bahwa implementasi kebijakan perlu dilakukan melibatkan masyarakat agar tujuan dari kebijakan tersebut dapat tercapai. 


\section{e. Pelaksana Program}

Program Gerbang Emas Bersinar dilaksanakan pada tahun 2014 dengan dipersiapkan Pemerintah Kabupaten Tabalong didukung dengan adanya pelaksanaan kebijakan yang kompeten dan kapabel untuk keberhasilan suatu kebijakan diantaranya; landasan dasar kebijakan, implementator, sumber pendanaan dan target penerima dampak. Landasan dasar kebijakan beberapanya telah diatur melalui Peraturan Bupati Nomor 18 Tahun 2014 tentang Pedoman Gerakan Pembangunan Menuju Masyarakat Sejahtera dan terbitnya Peraturan Daerah No. 31 Tahun 2017 tentang Pedoman Pelaksanaan Kredit Gerbang Emas. Kemudian, implementator yang terlibat dalam pelaksanaan Gerbang Emas Bersinar melalui Tim penyelenggara ditetapkan melalui Keputusan Bupati. Tim penyelenggara tersebut terdiri dari:

1. Tim Koordinasi di tingkat kabupaten; 2. Tim Sekretariat di tingkat kabupaten, dan 3. Kelompok Kerja di tingkat kecamatan. Sumber pendanaan Gerbang Emas Bersinar berasal dari APBDesa, APBD Kabupaten, APBD Provinsi, APBN, Corporate Social Responsibility (CSR), dan Swadaya Masyarakat.

f. Sumberdaya yang digunakan

Program Gerbang Emas Bersinar menggunakan berbagai sumber daya untuk mensukseskan pencapaian harapan Pemerintah Kabupaten Tabalong secara organisasi internal Satuan Kerja Peringkat Daerah (SKPD) disesuaikan dengan leading sector dinasdinas terkait dengan kebijakan Gerbang Emas Tim penyelenggara ditetapkan melalui Keputusan Bupati. Kemudian pelaksanaan juga didukung dengan pembentukan tim penyelenggara Gerbang Emas oleh Bupati diantaranya: 1. Tim Koordinasi di tingkat kabupaten; 2. Tim Sekretariat di tingkat kabupaten, dan 3. Kelompok Kerja di tingkat Kecamatan. Kemudian dari sumber pendanaan Gerbang Emas Bersinar berasal dari APBDesa, APBD Kabupaten, APBD Provinsi, APBN, Corporate Social Responsibility (CSR), dan Swadaya Masyarakat. Sumber daya lain, yang dikategorikan selanjutnya sebagai pendukung adalah sumberdaya dari dinas teknis, Unit Pengelolaan dan Pemasaran Bokar (UPPB), Perusahaan Umum Daerah (PERUMDA), LSM, Perusahaan, Yayasan, Univeritas untuk membantu mengawal proses kebijakan termasuk masukan yang membangun.

\section{Konteks Implementasi}

a. Kekuasaan, Kepentingan dan Strategi dari Aktor yang terlibat

Kekuasan terdapat pada Kepala Daerah Kabupaten Tabalong dan DPRD. Kemudian kepentingan dari pada Gerbang Emas Bersinar Kabupaten Tabalong adalah memajukan daerah dan kesejahteraan masyarakat melalui peningkatan IPM. Sementara, meninjau dari 
aspek strategi merupakan political will dari pemerintah yang diaktualisasikan dengan Peraturan Bupati No. 18 Tahun 2014 tentang tentang Pedoman Gerakan Pembangunan Menuju Masyarakat Sejahtera dan Peraturan dan Peraturan Daerah No. 31 Tahun 2017 tentang Pedoman Pelaksanaan Kredit Gerbang Emas. Munculnya peraturan tersebut tidak terlepas dari peran DPRD yang memberikan dukungan terhadap kebijakan tersebut. Hal tersebut berarti political will telah terbentuk baik pada kepala daerah sebagai eksekutif dan DPRD sebagai legislatif. Kesamaan political will tersebut kemudian terwujud dalam hubungan yang baik dan harmonis antara kepala daerah dengan DPRD.

b. Karakteristik Lembaga dan Penguasa

Karakteristik dari kebijakan Gerbang Emas dari sisi kelembagaan bersifat Top Down sebagai pola konsekuensi saat ini dengan kecenderungan inisiasi Pemerintah terhadap kebijakan kepada masyarakat. Penerima dampak terutama masyarakat apabila merujuk pada pembangunan IPM yang pesat seiring dengan implementasi Kebijakan Gerbang Emas tahun 2014 dengan membandingkan peringkat ke-3 terindikasi bahwa masyarakat antusias. Sementara, ditinjau dari insiasi Pemerintah sebagai penguasa, Program Gerbang Emas dilihat sebagai political will Pemerintah untuk mengentaskan permasalahan ekonomi, pendidikan, dan kesehatan yang sekaligus mendorong peningkatan IPM dan berujung pada kesejahteraan masyarakat.

c. Tingkat Kepatuhan dan Daya Tangkap Pelaksana Kebijakan

Pemerintah berkedudukan sebagai inisiator ditanggapi oleh masyarakat dentgan baik tidak ada tekanan dari masyarakat untuk tidak mensetujui dalam gerakan penolakan maupun menanggapi secara pasif dalam program. Antusias masyarakat yang posititf menjadi kekuatan dalam implementasi kebijakan Gerbang Emas Bersinar. Daya tangkap pelaksanaan kebijakan yang baik juga mampu dilihat dari antusiasnya pihak swasta patuh mendukung Gerbang Emas Bersinar melalui CSR seperti mendukung transportasi Bus Sekolah.

Sementara di sisi lain, Pemerintah Kabupaten Tabalong masih mengalami kendala terhadap SKPD yang dianggap masih belum mampu mengartikulasikan kebijakan Gerbang Emas Bersinar sesuai dengan kehendak Kepala Daerah. Permasalahan ini dapat ditangani dengan pola penyelenggaraan Gerbang Emas Bersinar secara mixed, di mana Kepala daerah kepada SKPD dan masyarkat kepada Kepala-Kepala Daerahnya melalui Musrembang kemudian dilakukan formulasi kebijakan yang tepat sesuai dengan bidang masing-masing. 


\section{E. KESIMPULAN}

Berbagai dinamika yang terjadi terhadap implementasi kebijakan Gerbang Emas Bersinar yang ada di Kabupaten Tabalong memberikan dampak terhadap peningkatan IPM. Kebijakan tersebut dirasa berhasil dalam mendorong percepatan pembangunan ekonomi dan meningkatkan kesejahteraan masyarakat melalui berbagai program yang sejalan dengan peningkatan kapasitas dan kualitas ekonomi. Adanya peningkatan ekonomi tersebut diharapkan mampu menjadi pemicu dalam perkembangan pendidikan dan kesehatan.

Analisis Implementasi Kebijakan pada Konteks Griendle mengungkapkan bahwa Kekuasan terdapat pada Kepala Daerah Kabupaten Tabalong dan DPRD. Kemudian kepentingan dari pada Gerbang Emas Bersinar adalah memajukan daerah dan kesejahteraan masyarakat melalui peningkatan IPM. Selain itu implementasi kebijakan pada koordinasi lintas lembaga terdapat sinergisitas kaitannya political will baik Kepala Daerah sebagai Eksekutif dan DPRD sebagai Legislatif. Kepatuhan dan daya tangkap program menunjukkan pola yang tidak berlawanan, pihak penerima dampak seperti masyarakat antusias terhadap kebijakan, yang diperkuat dengan argumen pesatnya peningkatan IPM. Kemudian, pelaksanaan kebijakan didukung dari berbagai pihak termasuk antusias perusahaan swasta dalam transfer sumberdaya melalui CSR.

\section{DAFTAR PUSTAKA}

Adisasmita, R. (2006). Pembangunan Perdesaan dan Perkotaan. Yogyakarta: Graha Ilmu. Arikunto, S. (1998). Prosedur Penelitian: Suatu Pendekatan Praktek. Jakarta: Rineka Cipta.

Arsyad, L. (1999). Pengantar Perencanaan dan Pembangunan, Ekonomi Daerah. Yogyakarta: BPFE.

Creswell, J. W. (2016). Pendekatan Metode Kualitatif, Kuantatif, dan Campuran.Yogyakarta. Pustaka Pelajar.

Dinar, A. L. (2015). Implementasi Program Gerakan Pembangunan Desa Terpadu (Gerbang Sadu) Mandara Di Desa Sibetan Kecamatan Bebandem Kabupaten Karangasem Bali (Studi Pada Kelompok Usaha Ekonomi Produktif). Publika, 3(5), 1-14.

Dye, T. R. (1978). Understanding Public Policy. New Jersey: Prentice Hall.

Effendy, K. (2010). Sosiologi Pemerintahan. Bandung: Indraprahasta.

Hanif, N. (2011). Pertumbuhan dan Penyelenggaraan Pemerintahan Desa. Jakarta: Erlangga.

Harli, M. (2013). Implementasi Program Gerakan Pembangunan Rakyat (Gapura) Sa-Ijaan di Desa Sungai Kupang Jaya Kecamatan Kelumpang Selatan Kabupaten Kotabaru Kalimantan Selatan. Jurnal Ilmu Politik \& Pemerintahan Lokal, 2(2), 302-310. 
Istianto, B. (2011). Manajemen Pemerintahan (Dalam Perspektif Pelayanan Publik), Jakarta: Mitra Wacana Media.

Jati, H., Astuti, I., \& Fernandez, D. (2015, November). Implementasi Inovasi Program Gerakan Membangun Ekonomi Masyarakat (Gerbang Emas) Dalam Meningkatkan Pendapatan Usaha Mikro Kecil di Kabupaten Flores Timur. In Seminar Nasional Riset Inovatif (Vol. 3).

Jones, C. O. (1996). Pengantar Kebijakan Publik. Jakarta: Raja Grafindo Persada.

Maryuni, S. (2016). Implementasi Program Nasional Pemberdayaan Masyarakat (PNPM) Mandiri Perkotaan di Kota Pontianak. PROYEKSI-Jurnal Ilmu Sosial dan Humaniora, 19(01).

Moleong, L. J. (2008). Metodologi Penelitian Kualitatif. Bandung: Remaja Rosdakarya.

Mudrajat, K. (2011). Perencanaan Daerah: Bagaimana Membangun Ekonomi Lokal, Kota dan Kawasan. Jakarta: Salemba Empat.

Nazir, M (2005). Metode Penelitian. Jakarta: Ghalia.

Ndraha, T. (2011). Kybernology (Ilmu Pemerintahan Baru). Jakarta: Rineka Cipta.

Peraturan Pemerintah Nomor 43 Tahun 2014 tentang Peraturan Pelaksana Undang-Undang Nomor 6 tahun 2014 tentang Desa.

Peraturan Menteri Dalam Negeri Nomor 86 Tahun 2017 tentang Tatacara Perencanaan, Pengendalian dan Evaluasi Rancangan Peraturan Daerah Tentang Rencana Pembangunan Jangka Panjang Daerah dan Rencana Pembangunan Jangka Menengah Daerah, Serta Tata Cara Perubahan Rencana Pembangunan Jangka Panjang Daerah dan Rencana Pembangunan Jangka Menengah Daerah dan Rencana Kerja Pemerintah Daerah.

Peraturan Menteri Dalam Negeri Nomor 114 tahun 2014 tentang Pedoman Pembanguna Desa.

Pudjianto, W. S. (2019). Pendekatan Baru Perencanaan Pembangunan Daerah. Jakarta: Kompas Media Nusantara.

Sinurat, M., \& Panjaitan, H. M. (2017). Perencanaan dan Penganggaran Daerah. Bandung: Pustaka Rahmat.

Suharyadi, H., \& Insani, M. A. (2016). Manajemen Pemerintahan Dalam Program Unit Reaksi Cepat Tambal Jalan di Kota Bandung Tahun 2015. Jurnal Ilmu Pemerintahan, 2(2), 241-243.

Suradinata, E. (1996). Manajemen Sumber Daya Manusia. Bandung: Ramadhan.

Undang-Undang Nomor 25 Tahun 2004 tentang Sistem Perencanaan Pembangunan Nasional.

Undang-undang Nomor 11 Tahun 2009 tentang Kesejahteraan Masyarakat Undang-Undang Nomor 6 Tahun 2014 tentang Desa.

Wasistiono, S. (2003). Kapita Selekta Manajemen Pemerintahan Daerah. Bandung: Fokusmedia. 